\title{
A RECORD OF BLUESPOTTED CORNETFISH, FISTULARIA COMMERSONII (ACTINOPTERYGII: SYNGNATHIFORMES: FISTULARIIDAE), OFF THE COAST OF BENGHAZI, LIBYA (SOUTHERN MEDITERRANEAN)
}

\author{
Houssein ELBARAASI* and Osama ELSALINI \\ Department of Zoology, Faculty of Science, Garyounis University, Benghazi, Libya
Elbaraasi H., ElSalini O. 2009. A record of bluespotted cornetfish, Fistularia commersonii (Actinopterygii: Syngnathiformes: Fistulariidae), off the coast of Benghazi, Libya (southern Mediterranean). Acta \\ Ichthyol. Piscat. 39 (1): 63-66.

\begin{abstract}
A record of bluespotted cornetfish Fistularia commersonii Rüppell, 1835, (Fistulariidae) from
\end{abstract} \\ the depth of $30 \mathrm{~m}$, caught off the coast of Benghazi, Libya (Southern Mediterranean), is reported herewith.
}

Keywords: bluespotted cornetfish, Fistularia commersonii, first record, Mediterranean, Libya

The opening of Suez Canal in 1869 connected the Red Sea to the Mediterranean and allowed the introduction of numerous Indo-Pacific species into the Mediterranean (Golani 1998a, 1998b, Kasapidis et al. 2007), including bluespotted cornetfish, Fistularia commersonii Rüppell, 1835 (cf. Golani 2000, Karachle et al. 2004, Golani et al. 2007).

The bluespotted cornetfish $F$. commersonii is distributed in tropical and subtropical seas, common among reefs, shallow sandy bottoms, and on sea grass beds (Fischer and Bianchi 1984, Golani et al. 2002). It lives either solitarily or in small groups preying chiefly on small fishes and small crustaceans such as shrimps, mysids, euphasiids, crabs, and other benthic crustaceans (Fischer and Bianchi 1984, Nakamura et al. 2003, Karachle et al. 2004, Froese and Pauly 2007). It is a Lessepsian migrant, recorded for the first time in the Mediterranean Sea off the coast of Israel by Golani (2000). Its geographical distribution has extended rapidly in the basin, with records from the Gulf of Gokova, Turkey (Bilecenoglu et al. 2002, Gokoglu et al. 2002), from the Rhodes Island, Greece (Corsini et al. 2002, Kalogirou et al. 2007), and from the Chalkidiki Peninsula, Greece (Karachle et al. 2004). It was also, recently reported from the central Mediterranean in Sicily, (Azzurro et al. 2004, Fiorentino et al. 2004) and Sardinia, Italy (Pais et al. 2007), Tyrrhenian Sea, Italy (Micarelli et al. 2006, Psomadakis et al. 2008), from Tunisian Coast (Ben Souissi et al. 2004, Charfi-Cheikhrouha 2004), from Libya (Shakman et Kinzelbach 2007), and from as far as Granada, Spain (Sanchez-Tocino et al. 2007). To date, the most recent records of the species was from the Adriatic Sea (Dulčić et al. 2008, Joksimović et al. 2008) and along the Algerian coasts, in Skikda Bay (eastern Algeria) and offshore of Bou Ismail Bay (central Algeria) at the Mediterranean (Kara and Oudjane 2008).

In this short note, a record of the bluespotted cornetfish, F. commersonii, in the Libyan waters is reported.

The specimen of $F$. commersonii was caught in November 2007 by a commercial bottom trawl, 5 nautical miles off the coast of Benghazi, Southern Mediterranean, Libya, (lat $32^{\circ} 06^{\prime} \mathrm{N}$, long $20^{\circ} 03^{\prime} \mathrm{E}$, Fig. 1) at the depth of approximately $30 \mathrm{~m}$. The fish was frozen on board the ship by fishermen. Once in the laboratory, the specimen was photographed (Fig. 2), and identified based on FAO Species Identification Sheets (Fischer and Bianchi 1984), and has been deposited in the Natural Museum of the Zoology Department, Faculty of Science, Garyounis University, Benghazi, Libya. The specimen had the typical morphometric and meristic diagnostic features of $F$. commersonii (cf. Golani 2000, Froese and Pauly 2007).

The specimen was $95.5 \mathrm{~cm}$ long (TL) and it weighed 395 g. It has very long tubular mouth, extremely elongated body shape and whip-like filamentous caudal middle rays. The body colouration was brownish to olive, with rows of blue spots and a pair of blue stripes along the back. White belly, fins with orange crest, transparent at base. Fin rays counts were: 16 dorsal, 15 anal, 14 pectoral, and 6 pelvic.

Stomach contents consisted of 3 small fish vertebral columns and remains of small euphasiids and crabs.

Over the last decade several investigators have reported the occurrence of new fish species in the Mediterranean basin (Dulčić and Grbec 2000, Dulčić et al. 2006, Francour 2008) including the Lessepsian

\footnotetext{
${ }^{*}$ Correspondence: Dr. Houssein Elbaraasi, Department of Zoology, Faculty of Science, Garyounis University, P.O. Box: 9480, Benghazi, Libya, phone: +218 91 379 4547, fax: +21861222 2805, e-mail: albrasi2000@yahoo.com
} 


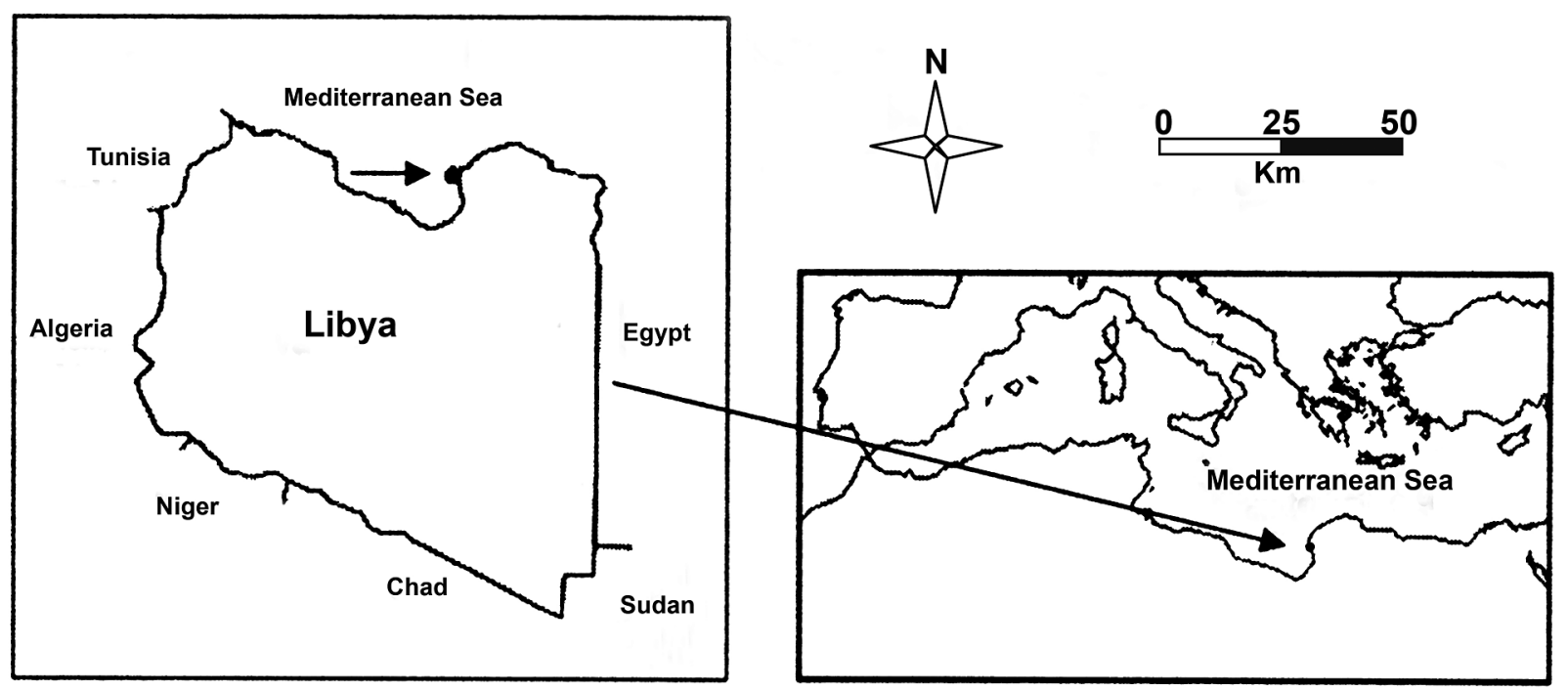

Fig. 1. Map showing where the herein reported specimen of Fistularia commersonii was collected off Benghazi, Libya

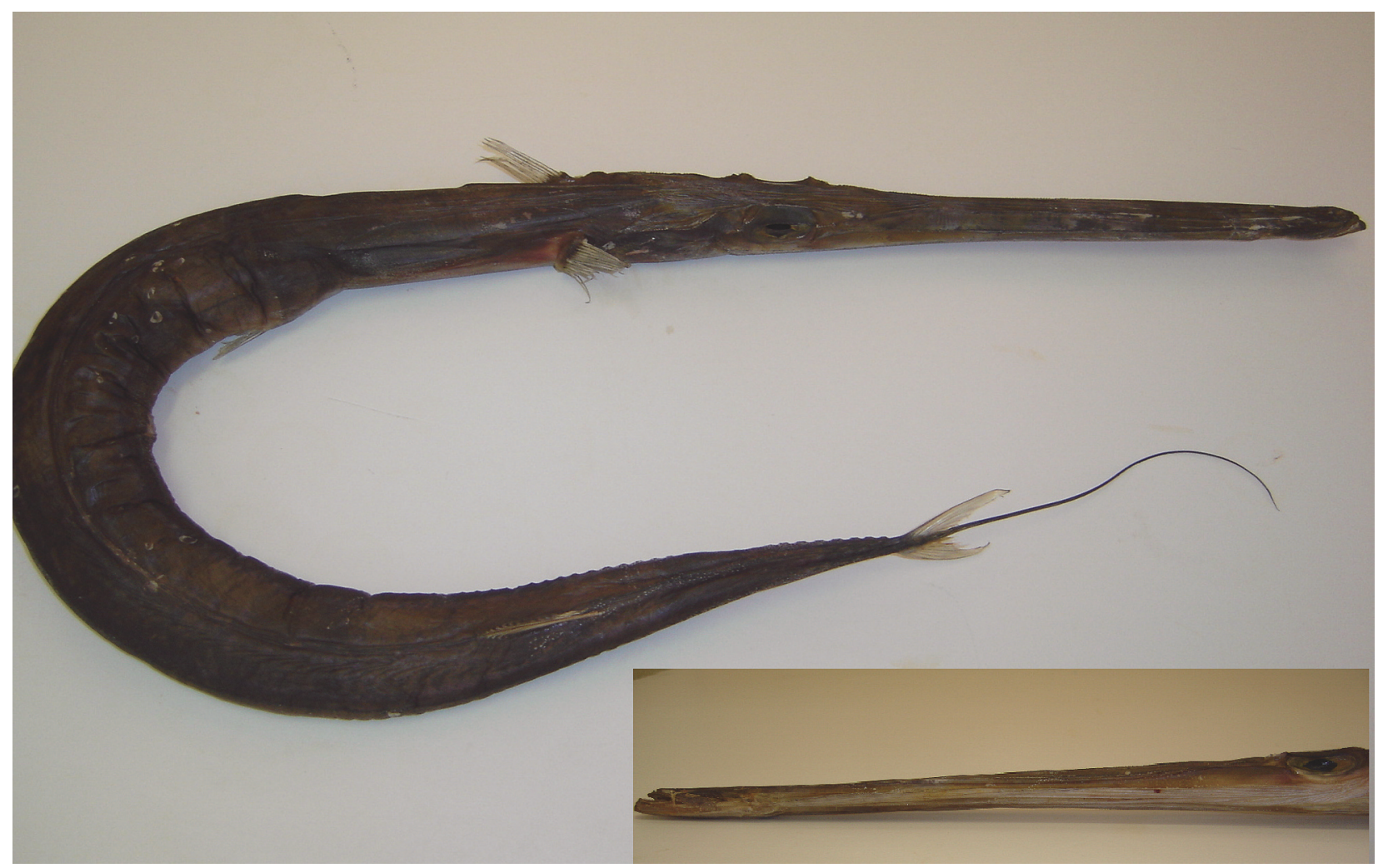

Fig. 2. Bluespotted cornetfish, Fistularia commersonii; inset shows head of the specimen

migrant fish $F$. commersonii that migrate from Red Sea via the Suez Canal (Golani et al. 2007). The presently reported finding represents the second record of this species in the coast of Benghazi, Libya, thus confirms its expansion in the southern Mediterranean. The cause of the increase could be a sign of climate changes, and water warming in the Mediterranean Sea and/or adaptation of the species to local condition (Dulčić et al. 2008, Garibaldi and Orsi-Relini 2008, Kara and Oudjane 2008).

Although, $F$. commersonii is now well established in the Mediterranean (Golani et al. 2007), the exact begin- ning of colonization or establishing a breeding population of the present record in the Libyan waters is difficult to determine. Therefore, more studies need to be done in the area where many new exotic species has been found recently (Elbaraasi et al. 2007).

\section{ACKNOWLEDGEMENTS}

Many thanks to two fishermen for providing the reported specimen. The authors wish to thank two anonymous reviewers for providing useful suggestions to improve the manuscript. 


\section{REFERENCE:}

Azzurro E., Pizzicori F., Andaloro F. 2004. First record of Fistularia commersonii (Fistularidae) from the central Mediterranean. Cybium 28: 72-74.

Ben Souissi J., Zaouali J., Bradai N., Quignard P. 2004. Lessepsian migrant fishes off the coast of Tunisia. First record of Fistularia commersonii (Osteichthyes, Fistularidae) and Parexocoteus mento (Osteichthyes, Exocoetidae). Vie et Milieu 54: 247-248.

Bilecenoglu M., Taskavak E., Kunt B. 2002. Range extension of three Lessepsian migrant fish (Fistularia commersonii, Sphyraena flavicauda, Lagocephalus suezensis) in the Mediterranean Sea. Journal of the Marine Biological Association of the United Kingdom 82: 525-526. DOI: 10.1017/S0025315402005829.

Charfi-Cheikhrouha F. 2004. Premières observations de quatre espèces de poissons allochtones à Rafraf (Nord-Est de la Tunisie). Bulletin de l'Institut National Scientifique et Technique de la Mer de Salammbô 31: 115-117.

Corsini M., Kondilatos G., Economidis S. 2002. Lessepsian migrant Fistularia commersonii from the Rhodes marine area. Journal of Fish Biology 60: 1061-1062. DOI: 10.1111/j. 1095-8649.2002.tb01865.x.

Dulčić J., Grbec B. 2000. Climate change and Adriatic ichthyofauna. Fisheries Oceanography 9: 187-191.

Dulčić J., Tutman P., Ćaleta M. 2006. Northernmost occurrence of the white grouper, Epinephelus aeneus (Perciformes: Serranidae), in the Mediterranean area. Acta Ichthyologica et Piscatoria 36: 73-75.

Dulčić J., Scordella G., Guidetti P. 2008. On the record of Lessepsian migrant Fistularia commersonii (Rüppell, 1835) from the Adriatic Sea. Journal of Applied Ichthyology 24: 101-102. DOI: 10.1111/j.1439-0426.2007.01022.x.

Elbaraasi H., Elmariami M., Elmeghrabi M., Omar S. 2007. First record of oilfish, Ruvettus pretiosus (Actinopterygii, Gempylidae), off the coast of Benghazi, Libya (Southern Mediterranean). Acta Ichthyologica et Piscatoria 37: 67-69.

Fiorentino F., Giusto B., Sinacori G., Norrito G. 2004. First record of Fistularia commersonii (Fistularidae, Pisces) in the strait of Sicily (Mediterranean Sea). Biologia Marina Mediterranea 11: 583-585.

Fischer W., Bianchi G. 1984. FAO species identification sheets for fishery purposes. Vol. 2. Western Indian Ocean (Fishing Area 51). FAO, Rome.

Francour P. 2008. First records of Didogobius splechtnai along the French Mediterranean coast and additional comments about $D$. schlieweni. Acta Ichthyologica et Piscatoria 38: 139-141. DOI: 10.3750/AIP2008.38.2.09.

Froese R., Pauly D. 2007. FishBase. http://www.fishbase.org

Garibaldi F., Orsi-Relini L. 2008. Record of the bluespotted cornetfish Fistularia commersonii Rüppell, 1838 in the Ligurian Sea (NW Mediterranean). Aquatic Invasions 3: 471-474. DOI: 10.3391/ai.2008.3.4.20.

Gokoglu M., Bodur T., Gulyavuz H. 2002. The first record of bluespotted cornetfish (Fistularia commersonii Rüppell, 1835) along the Turkish Mediterranean coast. Israel Journal of Zoology 48: 252-254. DOI: 10.1560/J3U8-NGCW-VDM2-3WWV.

Golani D. 1998a. Impact of Red Sea fish migrants through the Suez Canal on the aquatic environment of the eastern Mediterranean. Bulletin of Yale School of Forestry and Environmental Studies 103: 375-387.

Golani D. 1998b. Distribution of Lessepsian migrant fish in the Mediterranean. Italian Journal of Zoology 65 (Suppl.): 95-99. DOI: 10.1080/11250009809386801

Golani D. 2000. First record of bluespotted cornetfish from the Mediterranean Sea. Journal of Fish Biology 56: 1545-1547. DOI: 10.1111/j.1095-8649.2000.tb02163.x.

Golani D., Azzurro E., Corsini-Foka M., Falautano M., Andaloro F., Bernardi G. 2007. Genetic bottlenecks and successful biological invasions: the case of a recent Lessepsian migrant. Biology Letters 2007 (3): 541-545. DOI: 10.1098/rsbl.2007.0308.

Golani D., Orsi-Relini L., Massuti E., Quignard J.P. 2002. CIEM atlas of exotic species in the Mediterranean. In: Fishes, Vol. 1. Briand F. (ed.). CIESM Publisher, Monaco.

Joksimović A., Dragicević B., Dulčić J. 2008. Additional record of Fistularia commersonii from the Adriatic Sea (Montenegrin coast). JMBA 2 Biodiversity records 2008 (6232): 1-2. http://www.mba.ac.uk/jmba/pdf/6232.pdf.

Kalogirou S., Corsini M., Kondilatos G., Wennhage H. 2007. Diet of the invasive piscivorous fish Fistularia commersonii in a recently colonized area of the Mediterranean. Biological Invasions 9: 887-896.

Kara M.H., Oudjane F. 2008. First observations of the Indo-Pacific bluespotted cornetfish Fistularia commersonii (Fistulariidae) from Algerian coasts. JMBA2 - Biodiversity Records 2008 (6470): 1-4. http://www.mba.ac.uk/jmba/pdf/6470.pdf.

Karachle K., Triantaphyllidis C., Stergiou I. 2004. Bluespotted cornetfish, Fistularia commersonii Rüppell, 1838: A Lessepsian sprinter. Acta Ichthyologica et Piscatoria 34: 103-108.

Kasapidis P., Peristeraki P., Tserpes G., Magoulas A. 2007. A new record of the Lessepsian invasive fish Etrumeus teres (Osteichthyes: Clupeidae) in the Mediterranean Sea (Aegean, Greece). Aquatic Invasions 2: 152-154. DOI: 10.3391/ai.2007.2.2.12.

Micarelli P., Barlettani M., Ceccarelli R. 2006. Prima segnalazione di Fistularia commersonii (Rüppel, 1838) (Fistulariidae, Pisces) nel Tirreno settentrionale. Biologia Marina Mediterranea 13: 887-889. [In Italian.]

Nakamura Y., Horinouchi M., Nakai T., Sano M. 2003. Food habits of fishes in a seagrass bed on a fringing coral reef at Iriomote Island, southern Japan. Ichthyological Research 50: 15-22. DOI: 10.1007/s102280300002.

Pais A., Merella P., Follesa C., Garippa G. 2007. Westward range expansion of the Lessepsian migrant Fistularia commersonii (Fistulariidae) in the Mediterranean Sea, with notes on its parasites. Journal of Fish Biology 70: 269-277. DOI: 10.1111/j.1095-8649.2006.01302.x.

Psomadakis P.N., Scacco U., Consalvo I., Bottaro M., Leone F., Vacchi M. 2008. New records of the Lessepsian fish 
Fistularia commersonii (Osteichthyes: Fistulariidae) from the Central Tyrrhenian Sea: signs of an incoming colonization? JMBA 2 - Biodiversity records 2008 (6123): 1-7. http://www.mba.ac.uk/jmba/pdf/6123.pdf.

Sanchez-Tocino L., Hidalgo Puertas F., Pontes M. 2007. Primera cita de Fistularia commersonii Ruppell, 1838 (Osteichtyes: Fistulariidae) en aguas mediterráneas de la Península Ibérica. Zoologica Baetica 18: 79-84.
Shakman E.A., Kinzelbach R. 2007. Distribution and characterization of Lessepsian migrant fishes along the coast of Libya. Acta Ichthyologica et Piscatoria 37: 7-15.

Received: 21 February 2008

Accepted: 19 February 2009

Published electronically: 20 May 2009 